\title{
The Impact of Whistleblowing Awards Programs on Corporate Governance
}

\author{
Janet Austin* \\ Sulette Lombard**
}

Since the introduction of a whistle-blower awards program by the US Securities and Exchange Commission in 2010, securities regulators in other countries, including Canada, have adopted, or are considering adopting, similar programs. For example, in 2016, the Ontario Securities Commission adopted its own whistle-blower award program. Although the primary main reason for these programs is to encourage the reporting of securities violations to the regulator, they could also have an impact on corporate governance. This is because the implementation of such a program may prod companies to design, and then instigate, a more effective internal whistle-blowing system. A truly successful internal whistle-blowing system can enable a company to detect and correct potential wrongdoing before it causes significant harm. This article closely examines this connection between whistle-blowing award programs, companies' compliance and risk management systems, and how a whistle-blowing award program might well result in more effective internal whistle-blowing systems without the need for a regulator to resort to the imposition of prescriptive rules. As such, this article reflects upon how whistle-blower award programs fit within new governance regulatory theory that challenges traditional "command-andcontrol-type" regulation in favour of an outcome-driven approach.

Depuis que la US Securities and Exchange Commission a introduit un programme de primes de dénonciation d'abus en 2010, les organismes de surveillance des valeurs mobilières d'autres pays, dont le Canada, se sont dotés ou envisagent de se doter de programmes semblables. Ainsi, la Commission des valeurs mobilières de l'Ontario s'est dotée du sien en 2016. Certes, ces programmes ont pour principale raison d'être d'encourager la dénonciation des violations relatives aux valeurs mobilières auprès des organismes de surveillance mais ils peuvent également avoir un effet sur la gouvernance d'entreprise. C'est que la mise en ouvre d'un programme de cet ordre peut inciter les entreprises à concevoir et à mettre en place un meilleur système interne de dénonciation des abus. Lorsqu'il fonctionne bien, ce genre de système peut permettre à une entreprise de détecter les éventuels actes illicites et de prendre des mesures correctives avant que des dégâts importants ne soient faits. Dans cet article, les auteures se penchent sur le lien entre les programmes de primes de dénonciation d'abus, la conformité des entreprises et les systèmes de gestion des risques d'une part et sur la façon dont ces programmes permettent d'améliorer les systèmes internes de dénonciation d'abus sans qu'un organisme de surveillance ait à imposer des règles normatives. À ce titre, cet article est une réflexion sur la manière dont les programmes de primes de dénonciation d'abus s'imbriquent dans la nouvelle théorie de réglementation de la gouvernance, qui remet en question la méthode de " commandement et contrôle » et privilégie une démarche axée sur le résultat. 


\section{INTRODUCTION}

In 2010, the US Congress passed the Dodd Frank Wall Street Reform and Consumer Protection Act (Dodd Frank Act). ${ }^{1}$ The Dodd Frank Act contained a number of reforms to encourage whistle-blowers to report fraud and misconduct to the US Securities and Exchange Commission (SEC). It enhanced anti-retaliation protections for whistle-blowers and provided that whistle-blowers could make an anonymous report to the SEC. However, perhaps the most significant reform in relation to whistle-blowers was that the Dodd Frank Act directed the SEC to establish a whistle-blower awards program. ${ }^{2}$ Under this program, for the voluntary disclosure of original information that leads to a successful enforcement action resulting in the imposition of monetary sanctions of over US \$1 million, the SEC must pay the whistle-blower an award of between 10 and 30 percent of the amount collected from those sanctions. ${ }^{3}$ To date, the SEC has paid approximately US $\$ 160$ million in whistle-blower awards to forty-six individuals and has ordered wrongdoers in enforcement matters involving whistle-blower information to pay US $\$ 975$ million in total monetary sanctions. ${ }^{4}$

Inspired in part by the apparent success of this whistle-blower award program, the Ontario Securities Commission [OSC], the largest securities regulator in Canada, also introduced a whistle-blower award program in July 2016. ${ }^{5}$ This program provides that a whistle-blower may become entitled to an award of between 5 and 15 percent of the monetary sanctions imposed if the sanctions ordered against wrongdoers are CDN $\$ 1$ million or more. ${ }^{6}$ The primary rationale for the adoption of these award programs was to improve the efficiency and outcomes of enforcement actions by encouraging whistle-blowers to come forward to the regulator with high quality information. Furthermore, the hope was that better detection and enforcement might deter potential future violations because of the increased likelihood that regulators would be alerted to the misconduct. ${ }^{7}$ Yet there is an additional and possibly more significant benefit of such award programs that has been somewhat overlooked in the attention given to the potential for whistle-

* Janet Austin, Associate Professor, Faculty of Law, University of New Brunswick, Fredericton, Canada.

** Sulette Lombard, Senior Lecturer in Law, Flinders University, Bedford Park, Australia.

1 Dodd-Frank Wall Street Reform and Consumer Protection Act, Pub L No 111-203, para 922(a), 121 Stat 1894 (2010) (Dodd Frank Act). This was signed into law on 21 July 2010.

2 The Dodd Frank Act inserted a new para 21F into the Securities Exchange Act 1934, Pub L 73-291, 48 Stat 881 (codified at 15 USC $\S 78$ a et seq.) The final rules went into effect on 12 August 2011. See Implementation of the Whistleblower Provisions of Section $21 F$ of the Securities Exchange Act of 1934, 17 CFR Parts 240 \& 249 (12 August 2011) [SEC Implementation of Section 21F].

3 Ibid.

4 Securities and Exchange Commission (SEC), 2017 Annual Report to Congress Whistleblower Program (2017) at 1, online: <www.sec.gov/files/sec-2017-annual-report-whistleblower-program.pdf > [SEC 2017 Annual Report].

5 Ontario Securities Commission (OSC) Office of the Whistleblower, News Release, "OSC Launches Officer of the Whistleblower" (14 July 2016), online: <http://www.osc.gov.on.ca/en/NewsEvents_nr_20160714_osc-launcheswhistleblower.htm $\geq$.

6 The maximum whistle-blower award under the OSC program is set at CDN $\$ 1.5$ million if the aggregate amount of monetary sanctions and/or voluntary payments is equal to or greater than CDN \$10 million. However if the OSC actually collects the monetary sanctions and/or voluntary payments in an amount equal to or greater than CDN \$10 million, than the maximum award is increased to CDN \$5 million. See OSC Office of the Whistleblower, supra note 5; OSC, Policy 15-601 Whistleblower Program (14 July 2016) at para 18, online: $<\mathrm{http} / / / w w w . o s c . g o v . o n . c a / d o c u m e n t s / e n / S e c u r i t i e s-$ Category1/20160714_15-601_policy-whistleblower-program.pdf $>$ [OSC Policy 15-601].

7 SEC Implementation of Section $21 F$, supra note 2 at 238. 
blowers to receive very large rewards and the impact of such schemes on enforcement outcomes. This benefit is that, by incentivizing whistle-blowers to report misconduct to the regulators, it may have the effect of indirectly prodding companies to improve their internal whistle-blower reporting systems.

Internal whistle-blower reporting systems are methods and policies put in place by companies to encourage employees to report fraud and misconduct internally to management. If there are increased incentives for an employee to report misconduct outside of the organization, there will arguably be a heightened risk that a company may find itself the subject of enforcement action in relation to misconduct that the company has failed to discover and/or not appropriately addressed. Accordingly, one expected response to the introduction of a whistle-blower award program by a regulator should be the incentivizing of companies to enhance their internal compliance systems, and, in particular, their internal whistle-blower reporting mechanisms, so that the company receives early notification of wrongdoing from their employees. This would enable the company to take steps to remedy the reported misconduct before the harm caused by the wrongdoing escalates and before a whistle-blower employee takes steps to report the misconduct to a regulator.

While the main reason that the SEC and OSC advocated for whistle-blower award programs was to improve the outcomes of their enforcement actions, both organizations were cognizant of the potential impact that their whistle-blower award programs would have on internal compliance systems. In announcing its program, the SEC stated:

[I]ssuers who previously may have underinvested in internal compliance programs may respond to our rules by making improvements in corporate governance generally, and strengthening their internal compliance programs in particular. While these improvements will involve costs on companies, there should be an overall increased efficiency from the perspective of investors to the extent that these companies achieve a more optimal investment in these programs. ${ }^{8}$

Similarly, the OSC stated that, in addition to incentivizing whistle-blowers to come forward, the aim of its program included motivating companies to self-report misconduct so that they could avail themselves of the OSC's credit for cooperation program. ${ }^{9}$ Such credit for cooperation will generally not be available if the OSC receives a report from the whistle-blower first. ${ }^{10}$ As such, the former chair of the OSC's Office of the Whistleblower described the program as an opportunity for companies to review and enhance their compliance systems and to foster an environment where internal reporting of misconduct is encouraged. ${ }^{11}$ In this article, we seek to explore the relationship between whistle-blower award programs and companies' internal compliance systems. We then discuss these impacts within the new governance, smart regulation,

$8 \quad$ Ibid at 239.

9 Proposed Framework for an OSC Whistleblower Program, OSC Staff Consultation Paper 15-401 (3 February 2015) at 5, online $<$ http://www.osc.gov.on.ca/documents/en/Securities-Category1/rule_20150203_15-401_whistleblowerprogram.pdf $>$ [OSC Proposed Framework].

10 Ibid.

11 Heidi Franken, "Whistleblowing Bounties as an Anti-Corruption Measure 2017" (Panel discussion, delivered at Flinders University, 21 June 2017), online:

<video.flinders.edu.au/events/Whistleblowing_Bounties_as_an_AntiCorruption_Measure_2017.cfm>. 
and "nudge theory" literature. By adopting such award programs, the regulators seem to be hoping to influence companies to design and implement a more tailored and robust internal whistle-blower system without the regulator having to resort to prescriptive regulations to force companies to adopt such a system, which would arguably be an undesirable approach for a number of reasons. ${ }^{12}$ As such, Part II briefly outlines the whistle-blower award programs adopted by the SEC and the OSC and what factors led each of these regulators to press for such a program. Part III considers the compliance and risk management functions within companies and the role played by internal whistle-blower reporting mechanisms as part of this compliance function. Part IV then moves on to consider how the design of effective internal whistle-blower reporting systems is aided by so-called "smart regulation" theory - that is, a form of regulation that emphasizes collaboration between the regulator and the organization being regulated - rather than by a rules-based, top-down approach from the regulator. We then consider how whistle-blower award programs can work to enhance regulatory outcomes in such a collaborative environment by "nudging" corporations to improve internal whistle-blower compliance systems and by rewarding companies that respond appropriately to internal disclosures of misconduct. We conclude by emphasizing that whistle-blower award programs can be a useful mechanism to improve the governance of an organization by enhancing both the design of internal whistle-blowing systems and the response of companies to internal reports of misconduct. However, we also caution that care must be taken in the design of whistle-blowing award programs by regulators so that they enhance, rather than detract, from companies' internal compliance systems.

\section{THE INTRODUCTION AND RATIONALE BEHIND THE SEC'S AND OSC'S WHISTLE- BLOWER AWARD PROGRAMS}

\section{A. The SEC's Whistle-blower Award Program}

The Dodd Frank Act, which came into effect in 2010, was the most significant piece of financial reform legislation enacted in response to the 2008 global financial crisis. ${ }^{13}$ Contained within it were enhanced protections for whistle-blowers, including provisions in relation to a whistle-blower award program to be administered by the SEC. ${ }^{14}$ Although some of the provisions in the Dodd Frank Act generated significant debate during congressional hearings, there was relatively little debate on these whistle-blowing provisions. ${ }^{15}$ Perhaps this was because it was the SEC itself that had asked Congress for legislation to enable it to set up such a program. ${ }^{16}$ The SEC sought such a program in response to public criticism of its

12 See Part III for further discussion.

13 For a description of all the provisions and the events leading up to the Dodd Frank Act, see Michael S Barr, "The Financial Crisis and the Path of Reform" (2012) 29 Yale J Reg 91.

14 Dodd Frank Act, supra note 1.

15 Geoffrey Rapp, "Mutiny by the Bounties: The Attempt to Reform Wall Street by the New Whistleblower Provisions of the Dodd-Frank Act" (2012) 73 BYU L Rev 73 at 89.

16 This provisions were inserted into the Dodd Frank Act in response to the Securities and Exchange Commission (SEC) seeking such a program in a proposed Investment Protection Act, which the Obama administration took to Congress on 10 July 2009. See US Department of the Treasury, Fact Sheet, “Administration's Regulatory Reform Agenda Moves Forward Legislation for Strengthening Investor Protection Delivered to Capitol Hill” (10 July 2009), online: $<$ http://www.treasury.gov/press-center/press-releases/Pages/tg205.aspx $>$. The Investment Protection Act would have 
failure to respond to numerous tips about the fraudulent operations of Bernard Madoff as well as the corporate governance failures exposed by the events that contributed to 2008 global financial crisis. ${ }^{17}$ Given these debacles, it seems that many within the SEC believed that it needed a broad-based financial reward scheme to incentivize whistle-blowers to come forward to report fraud and misconduct so that the SEC could take action before it caused significant harm, rattled investors and the capital markets, and embarrassed the SEC. ${ }^{18}$

Importantly, the Dodd Frank Act was not the first attempt by Congress and the SEC to try to foster an environment whereby whistle-blowers would be incentivized to come forward to report corporate fraud and misconduct. In 2002, in the wake of the collapses of Enron and Worldcom, the US Congress had expanded the scope of whistle-blower protections by the passage of the Sarbanes Oxley Act (SOX) ${ }^{19}$ SOX grants private sector employees protection from retaliation for blowing the whistle and the right to bring a claim in federal court for reinstatement, back pay, and/or compensation. ${ }^{20}$ It also sets a relatively low standard to acquire such protection, being only that the whistle-blower had a "reasonable belief of fraud." 21 SOX also required audit committees of listed public companies to set up internal whistle-blowing procedures for receiving anonymous complaints from employees in relation to accounting and audit matters. ${ }^{22}$

Nevertheless, in the years following the passage of SOX, one study found that the number of employees blowing the whistle on corporate fraud actually had fallen from 19 percent to 13 percent. ${ }^{23}$ Furthermore, the fact that the $S O X$ reforms did not serve to prevent the global financial crisis perhaps demonstrates the shortcomings of these provisions. Mirian Baer suggests that it is because anti-retaliation laws can only go so far in that back pay and the threat of lawsuits cannot protect employees from subtle stigma and discrimination. ${ }^{24}$ The lack of success of the SOX reforms also demonstrates perhaps that, from a behavioural perspective, encouraging whistle-blowing is difficult:

allowed the SEC to pay whistle-blowers a reward of up to 30 percent for information that led to monetary penalties that were over US \$1 million. The Dodd Frank Act removed some of the discretion vested in the SEC in determining the amount of the reward. Whereas the Investment Protection Act would have given the SEC the discretion to pay up to 30 percent, the Dodd Frank Act provides that a whistle-blower providing original information to the SEC is entitled to a minimum award of 10 percent and a maximum of 30 percent if monetary penalties over US \$1 million are imposed. The Dodd Frank Act also allows for judicial review of a decision by the SEC not to pay an award, something that was not included in the Investor Protection Act.

17 For a description of the Madoff scandal, see Donald C Langevoort, "The SEC and the Madoff Scandal: Three Narratives in Search of a Story" (2009) Mich St L Rev 899.

18 Mirian H Baer, "Reconceptualizing the Whistleblower's Dilemma" (2017) 50 UC Davis L Rev 2215 at 2226.

19 Sarbanes Oxley Act, 2002 Pub L No 107-204 § 806, 116 Stat 745 (2002) [SOX]. See generally Terry M Dworkin, "Sox and Whistleblowing" (2007) 105:8 Mich L Rev 1757.

20 Sarbanes Oxley Act, supra note 19 at para 806.

21 Ibid at para 1514A(b). See generally Meghan Elizabeth King, "Blowing the Whistle on Dodd-Frank Amendments: The Case against the New Amendments to the Whistleblower Protection in Section 806 of Sarbanes-Oxley" (2011) 48 Am Crim L Rev 1457.

22 Sarbanes Oxley Act, supra note 19 at para 301.

23 Alexander Dyck, Adair Morse \& Luigi Zingales, "Who Blows the Whistle on Corporate Fraud?" 65:6 Journal of Finance 65 at 2213.

24 Baer, supra note 18 at 2226. 
Norms of loyalty are immensely powerful ... and self-serving interference will often cut against forming the impression that a colleague is cheating. Tone at the top and peer support seem crucial; as one set of commentators put it: "it takes a village" to have the right support and incentives for whistleblowers to act. ${ }^{25}$

Some academic commentators also attributed $S O X$ 's lack of success in encouraging whistle-blowers to its focus on merely protecting whistle-blowers from retaliation, even though the empirical evidence increasingly appears to show that offering a reward is the most effective mechanism to spur whistleblowing. ${ }^{26}$ To this end, some academics pointed to evidence of the success of the qui tam provisions of the False Claims Act in motivating employees to come forward to report fraud. ${ }^{27}$ The False Claims Act allows private individuals to sue government contractors who have defrauded the US government in return for a proportion of the proceeds. ${ }^{28}$ It seems that employees who may become entitled to such a reward are much more likely to come forward than if they were not entitled to such a reward. ${ }^{29}$

Despite this apparent failure of $S O X$ to provide a sufficient incentive to whistle-blowers to report fraud, it was not until 2009 that there was renewed interest within the SEC to revisit this issue, and this impetus largely came from the damage caused by the Bernard Madoff Ponzi scheme and the global financial crisis. It was only then that the SEC seems to have come to the realization that the status quo was not sufficiently effective in encouraging whistle-blowing, and, as such, the SEC needed a reward scheme for whistleblowers..$^{30}$ The SEC also seems to have been inspired by the apparent success of a similar award program operated by the US Internal Revenue Service that had significantly increased the number of persons coming forward to report tax fraud. ${ }^{31}$ This resulted in the SEC seeking legislation granting it the power to award whistle-blowers for information leading to a successful enforcement action. ${ }^{32}$ This request for legislation by the SEC eventually resulted in the changes introduced by the Dodd Frank Act. ${ }^{33}$

The SEC released its proposed rules for the whistle-blower award program on 3 November $2010,{ }^{34}$ and its final rules went into effect on 12 August $2011 .{ }^{35}$ Although it is clear that the rationale for the program

25 Donald C Langevoort, "Behavioral Ethics, Behavioral Compliance" in Jennifer Arlen, ed, Research Handbook on Corporate Crime and Financial Misdealing (Cheltenham, UK: Edward Elgar, 2018) 274.

26 Dworkin, supra note 19; King, supra note 21; Rapp, supra note 15.

27 Dyck, Morse \& Zingales, supra note 23.

28 False Claims Act 1863, 31 USC §§ 3729-3733; see also Robert Vaughn, The Successes and Failures of Whistleblower Laws (Cheltenham, UK: Edward Elgar, 2012) at 127.

29 Dyck, Morse \& Zingales, supra note 23.

30 See Jordan Thomas, "Comments" (Roundtable Discussion re Whistleblower Roundtable, OSC, 9 June 2015) at 37-38, online: <http://www.osc.gov.on.ca/en/SecuritiesLaw_rule_20150609_15-401_whistleblower-program-roundtabletranscript.htm>.

31 Mark Jickling, "The Dodd-Frank Wall Street Reform and Consumer Protection Act: Title IX, Investor Protection," CRS Report to Congress (24 November 2010) at 3, online: <http://www.llsdc.org/assets/DoddFrankdocs/crs-r41503.pdf >.

32 M Shapiro, Testimony to the Subcommittee of Financial Services and General Government Appropriations Committee, 111th Congress (2 June 2009) at 10, online: <http://www.scribd.com/document/328584364/SENATE-HEARING111TH-CONGRESS-FINANCIAL-SERVICES-AND-GENERAL-GOVERNMENT-APPROPRIATIONS-FORFISCAL-YEAR-2010>

33 See generally note 16 above.

34 SEC Implementation of Section $21 F$, supra note 2.

35 SEC, Whistleblowers Incentive and Protections Final Rules, Doc 17 CFR Parts 240 \& 249 (12 August 2011), online: $<$ https://www.sec.gov/rules/final/2011/34-64545.pdf> [SEC Final Rules]. 
primarily was to enhance enforcement outcomes, the SEC did note in its final rules that one response to the program may be to prod companies to develop and improve their compliance systems. ${ }^{36}$ It stressed that the rules were not intended to create any new or special duties of disclosure on entities to report violations or possible violations of law to the SEC or to other authorities. ${ }^{37}$ Nevertheless, it did refer to the fact that when it considers whether to grant leniency to entities cooperating in the SEC's investigations and related enforcement actions, it takes into account the promptness with which entities voluntarily selfreport their misconduct. ${ }^{38}$ More recently, the SEC has reiterated its approach in granting organizations leniency as part of its Enforcement Cooperation Program, ${ }^{39}$ whereby the SEC takes into account four main factors in granting leniency - namely, self-policing prior to the discovery of the misconduct (including establishing effective compliance procedures and an appropriate tone at the top), self-reporting, remediation efforts, and cooperation with law enforcement authorities. ${ }^{40}$

One particularly contentious issue for the SEC in developing the final rules for the whistle-blower award program was that some in the business community had argued that the program would divert whistle-blowers away from reporting internally by way of internal whistle-blowing procedures that many companies had adopted because of the $S O X$ requirements. It was argued that businesses would experience significant costs as a result. ${ }^{41}$ In response, the SEC noted that none of the commentators had provided projections or estimates of these costs and cited a study by Anthony Heyes and Sandeep Kapur that suggested that a sizeable percentage of whistle-blowers who report internally are in fact motivated by nonmonetary reasons. From this, the SEC concluded that it anticipated that many whistle-blowers would continue to report internally first. ${ }^{42}$

Nevertheless, the final rules released by the SEC did make some modifications to the draft rules in an attempt to address these concerns and encourage whistle-blowers to report internally first. The rules provide that a whistle-blower who reports internally can be entitled to a reward if they also report to the SEC or related authority within 120 days of reporting internally. ${ }^{43}$ Furthermore, in deciding on the amount of the award, the SEC will consider favourably the fact that a whistle-blower first reported the fraud internally. ${ }^{44}$ In fact, since the program has been operational, figures released from the SEC appear to show that its whistle-blowing award program does not significantly disrupt internal compliance systems in that

$36 \quad$ Ibid at 238.

37 Ibid at 76

38 Ibid. The SEC referred to the Report of Investigation Pursuant to Section 21(a) of the Securities Exchange Act of 1934 and Commission Statement on the Relationship of Cooperation to Agency Enforcement Decisions SEC (23 October 2001), online: <http:/www.sec.gov/litigation/investreport/34-44969.htm>, which sets out some of the factors the SEC considered in granting leniency.

39 SEC, Enforcement Cooperation Program, online: <https://www.sec.gov/spotlight/enforcement-cooperationinitiative.shtml $\geq$.

40 Ibid.

41 SEC Final Rules, supra note 35 at 229.

42 Ibid. The SEC cited in support Anthony Heyes \& Sandeep Kapur, "An Economic Model of Whistleblower Policy" (2009) 25 JL Econ \& Org 157.

43 SEC Final Rules, supra note 35 at 231; 17 CFR $\S 240.21 \mathrm{~F}-4(\mathrm{c})(3)$ (2011)

44 SEC Final Rules, supra note 35 at 231; 17 CFR $\S 240.21 \mathrm{~F}-6(4)$ (2011). This is in addition to the provisions included in the proposed rules that require that, in determining the amount of the award, the SEC will consider whether or not the whistle-blower substantially and unreasonably delayed reporting the violations in assessing the amount of the award and 
most whistle-blowers who report to the SEC first report the problem internally. ${ }^{45}$ This is consistent with empirical studies in other areas where whistle-blowing rewards are available. ${ }^{46}$

\section{B. The OSC's Whistle-blower Award Program}

Like the SEC's award program, the driving force behind the adoption of the OSC's whistle-blower award program were employees of the OSC and, in particular, the OSC's enforcement division. ${ }^{47}$ This enthusiasm for adopting such a program may have been motivated by criticism over several years that the OSC was lax in taking enforcement action compared to the SEC. ${ }^{48}$ It was even suggested that this low level of enforcement has resulted in a higher cost of capital for companies seeking to raise funds in Canada, compared to raising funds in the United States. It is surmised that this is because investors require a higher return on their funds because there is a greater risk of fraud in Canadian companies. ${ }^{49}$ The OSC also took note of the apparent success of the SEC's whistle-blower award program, as indicated by the increasing number of tips the SEC was receiving each year since its introduction and by virtue of statements by the SEC that over half of the tips it had received related to complex cases involving sophisticated players that would have been difficult to uncover without the assistance of the whistle-blower. ${ }^{50}$ Furthermore, Canadians were actually contacting the SEC under its whistle-blower awards program, which seemed to

will view the fact that a whistle-blower intentionally interfered with his or her company's compliance system as a negative factor. See SEC Final Rules, supra note 35 at 125

45 The SEC reports that 83 percent of SEC whistle-blowers who were current or former employees reported that they raised their concerns internally first. See SEC 2017 Annual Report, supra note 4 at 17. It should be noted that there has been some criticism of some aspects of the SEC's awards program. For example, Yehonatan Givati, "Of Snitches and Riches: Optimal IRS and SEC Whistleblower Rewards" (2018) 55 Harv J on Legis 105, argues that the SEC should change the way the amount of the reward is determined. Furthermore, Givati provides a summary of other academic commentary of the program. These include criticisms that the program should mandate that employees first report internally, that the program makes fraud-on-the-market class actions weaker, and that the program has changed the focus of SEC enforcement programs (at 119-121). Givati also cites research from experimental surveys that have shown that, in some circumstances, offering monetary rewards may be unnecessary and even counterproductive (at 121).

46 In a study by Kesselheim, Studdert, and Mello, eight out of the twenty-two insiders interviewed tried first to fix the problem internally by talking to their superiors, filing an internal complaint, or both. See Aaron S Kesselheim, David M Studdert \& Michelle M Mello, "Whistle-Blowers' Experiences in Fraud Litigation against Pharmaceutical Companies" (2010) 19 New England Journal of Medicine 362 at 1832; see also a study by Bowen, Call, and Rajgopal that found that whistle-blowing complaints are usually justified in terms of disclosing previously unknown issues, are not usually motivated by those with an axe to grind or to avoid disciplinary proceedings, and can result in improved compliance. Robert M Bowen, Andrew C Call \& Shivaram Rajgopal "Whistle-Blowing: Target Firm Characteristics and Economic Consequences" (2010) 85(4) Account Review 1239.

47 Franken, supra note 11.

48 See for example Paul Halpern et al, Back from the brink: lessons from the Canadian asset-backed commercial paper crisis (Toronto: University of Toronto Press, 2016), V Sukdeo, "Corporate Crime: The Need to Increase Enforcement and Compliance (29 June 2009) CLEA 2009 Annual Meeting Paper, online: SSRN

$<$ https://papers.ssrn.com/sol3/papers.cfm?abstract_id=1427508> and Poonam Puri, "Securities Litigation and Enforcement: The Canadian Perspective" (2012) 37(3) Brook J Intl L 967.

49 John C Coffee, "Law and the Market; The Impact of Enforcement" (2007) 156 U Pa L Rev 268.

50 OSC Proposed Framework, supra note 9 at 1. 
suggest that there was an appetite from whistle-blowers in Canada for such a program..$^{51}$ The OSC also conducted its own research about what drives people to blow the whistle and found that, although most whistle-blowers are not motivated by financial incentives, financial incentives may offer whistle-blowers a "security blanket" in the event that they suffer retaliation. ${ }^{52}$

The OSC finalized the rules for its whistle-blower award program in July $2016 .{ }^{53}$ Similar to the SEC's program, the program has three key features. These are, first, protecting the identity of whistle-blowers. Second, shielding whistle-blowers from retaliation, and, third, offering them financial incentives. ${ }^{54}$ The primary aim of the program was to motivate those with information to come forward and, in particular, those privy to information that would otherwise be difficult to obtain. In addition, the program was designed to increase the number of investigations undertaken by the OSC and, at the same time, improve the efficiency of those investigations by obtaining high quality information from knowledgeable individuals. However, the OSC was also aware that the award program might result in companies reviewing and enhancing their compliance systems to foster an environment where internal reporting of misconduct is encouraged. ${ }^{55}$ To this end, the OSC noted that the award program was designed to work with the OSC's credit for cooperation program. ${ }^{56}$ This program is designed to encourage companies to self-police, self-report, and self-correct misconduct that is discovered. ${ }^{57}$ Under this program, companies that do effectively self-police, take corrective action, report breaches to the OSC promptly, and cooperate with its investigation will be treated with leniency in terms of enforcement action taken by the OSC. However, if a whistle-blower reports misconduct to the OSC before the company reports the misconduct, the OSC's credit for cooperation program will generally not apply. ${ }^{58}$ Therefore, the OSC hopes that the whistle-blower awards policy, working together with its credit for cooperation program, will prod companies to develop and improve their own compliance systems.

In this respect, it is relevant to note that in 2005 Canadian securities regulators had followed the United States in prescribing $S O X$, including requirements on audit committees of listed public companies. These require that a mechanism be set up whereby whistle-blowers can make anonymous complaints about audit

51 Franken, supra note 11. Canadians are consistently in the top three groups of foreign nationals contacting the SEC under its whistle-blower award program. See e.g. SEC, 2012 Annual Report to Congress Whistleblower Program (2012), Appendix C, online: <https://www.sec.gov/files/annual-report-2012.pdf>. SEC, 2013 Annual Report to Congress Whistleblower Program (2013), Appendix D, online: <https://www.sec.gov/files/annual-report-2013.pdf>. SEC, 2014 Annual Report to Congress Whistleblower Program (2014), Appendix C, online:

$<$ https://www.sec.gov/about/offices/owb/annual-report-2014.pdfs.

52 Franken, supra note 11.

53 OSC Office of the Whistleblower, supra note 4; OSC Proposed Framework, supra note 9.

54 OSC Proposed Framework, supra note 9 at 1.

55 Franken, supra note 11.

56 OSC, OSC Staff Notice 15-702 Revised Credit for Cooperation Program (13 March 2014). online: $<\mathrm{http} / / / w w w . o s c . g o v . o n . c a / d o c u m e n t s /$ en/Securities-Category1/sn_20140311_15-702_revised-credit-coopprogram.pdf $>$.

57 Ibid.

58 OSC Proposed Framework, supra note 9 at 5. This credit for cooperation program provides for various levels of leniency depending upon factors such as when the conduct is reported, the type of conduct, and the organization's response to the misconduct. The reward program is structured such that, if the OSC first hears of the misconduct by a whistle-blower rather than by the organization, the organization would be ineligible for credit for cooperation. 
and accounting matters. ${ }^{59}$ Around the same time, Canadian securities regulators also adopted National Policy 58-201. ${ }^{60}$ Although not legally binding, this policy provides that boards should adopt a written code of business conduct and ethics that specifically addresses the reporting of illegal or unethical behaviour. ${ }^{61}$ Like the SEC, many of the initial responses from business groups to the proposal that the OSC adopt a whistle-blower award policy were primarily concerns about the impact such a program would have on internal compliance procedures and internal whistle-blowing systems. ${ }^{62}$ Some commentators suggested that to be eligible for an award, the policy should require whistle-blowers to first report the misconduct through an internal compliance reporting mechanism before they approached the OSC. ${ }^{63}$ However, like the SEC, in the final policy, the OSC decided not to require that a whistle-blower first report the matter internally. Rather the OSC's whistle-blowers program states that the OSC endeavours to encourage internal reporting and, as such, the OSC will consider as a positive factor in determining the amount of the award the fact that the whistle-blower first reported the matter internally. ${ }^{64}$

Furthermore, similar to the SEC's whistle-blower award program, the OSC's whistle-blower program also provides that a whistle-blower who first reports via an internal compliance mechanism may, in some circumstances, still be entitled to an award even if the OSC hears of the matter from the whistle-blower's employer first. For example, if the whistle-blower reports the matter internally and the whistle-blower's employer then reports the matter to the OSC, the whistle-blower may be entitled to a whistle-blower award provided that whistle-blower reported the information to the OSC within 120 days of the initial internal report. $^{65}$

\section{COMPLIANCE, RISK MANAGEMENT, AND INTERNAL WHISTLE-BLOWING REPORTING SYSTEMS}

\section{A. The Compliance and Risk Management Functions}

Corporate compliance is the procedure by which an organization polices its own conduct to ensure that it conforms to applicable rules and regulations. ${ }^{66}$ Compliance procedures are necessary because in a complex organization individuals may not act in accordance with a particular standard on their own and

59 See Audit Committees, Doc BCSC NI 52-110 (17 March 2008) at para 2.3(7) (originally adopted as Doc MI 52-110 (30 June 2005). It became a national instrument when it was adopted by the British Columbia Securities Commission on 17 March 2008. In relation to the response in Canada to SOX, supra note 19, see David Johnston, Kathleen Rockwell \& Cristie Ford, Canadian Securities Regulation, 5th ed (Toronto: LexisNexis Canada, 2014) at 711.

60 Corporate Governance Guidelines, Corporate Social Responsibility National Policy 58-201 (17 June 2005) at para $3.8(\mathrm{f})$.

61 Ibid.

62 OSC, Comment Letters for 15-401: Proposed Framework for an OSC Whistleblower Program (2015), online: $<$ http://www.osc.gov.on.ca/en/47462.htm>.

63 Ibid. For comment, see Letter from Atul Tiwari, Managing Director, Vanguard Investments Canada Inc to the Ontario Securities Commission, 4 May 2015, online: <http://www.osc.gov.on.ca/documents/en/Securities-Category1Comments/com_20150504_15-401_tiwaria.pdf $>$.

64 OSC Policy 15-601, supra note 6 at para 25(2)-(3).

65 Ibid at para 16. For a criticism of the OSC's whistle-blower's award scheme, see Todd L Archibald, Kenneth E Jull \& Kent W Roach, Regulatory and Corporate Liability from Due Diligence to Risk Management (Toronto: Thomson Reuters Canada, 2017) at 7-29.

66 Geoffrey Miller, The Law of Governance, Risk Management and Compliance (New York: Walters Kluwer, 2014$)$ at 2-3. 
generally need some form of guidance, incentive, or compulsion. ${ }^{67}$ Compliance is linked to risk management in that risk management refers to the processes adopted by the organization by which risks are identified and analyzed and then a decision is made to either accept the risk or employ risk mitigation tactics. ${ }^{68}$ For most organizations, a significant category of such risks includes the risk of breaching the rules and regulations that govern the organization's activities. This is because a violation of such rules can impose significant costs on the organization. Such costs not only include the direct costs of penalties imposed on the organization if prosecuted but also the legal costs and reputational costs that frequently exceed the cost of any direct penalties imposed. ${ }^{69}$ Both the compliance and risk management functions form part of the governance of an organization in that decisions have to be made about how an organization is going to police its own behaviour (for example, by identifying, analysing, and managing risks) and how the organization is going to respond if misconduct is detected.

If the compliance and risk management procedures within an organization operate properly, the organization will police itself. It will identify potential violations of rules and regulations and stop these before they occur or, at the very least, mitigate the harm caused. If the compliance and risk management procedures operate properly throughout the business community, regulators will have to devote fewer resources to investigating and bringing enforcement actions, and the costs of monitoring will be borne by the organization rather than, for example, by external inspectors. There will also be less harm caused to the public and the economy generally from fraud and misconduct. As such, it is advantageous for regulators to cultivate an environment in which organizations adopt robust compliance and risk management policies and procedures.

\section{B. Internal Whistle-blowing Systems Form Part of the Compliance Function}

It has long been recognized that internal whistle-blowing reporting mechanisms can form an important part of the compliance and risk management functions. This is because such systems can give the organization the ability to expose wrongdoing that may not have otherwise been detected or may not have been detected until much later, thus preventing or reducing the harm that could potentially have resulted from the particular conduct. ${ }^{70}$ In terms of governance, the benefits of effective internal whistle-blowing mechanisms include the fact that a well-developed internal system provides a "signal" to would-be whistle-blowers that disclosures of wrongdoing are encouraged, thus creating a culture of transparency

\section{Ibid at 137.}

Ibid at 2.

69 Jonathan M Karpoff, D Scott Lee \& Gerald S Martin, "The Cost to Firms of Cooking the Books" (2008) 43 Journal of Financial and Quantitative Analysis 581.

70 See Stephane Rousseau, "Whistleblowing: An Instrument Serving Compliance" (2016) 50 RJT 571 at 579; Tom Devine \& Tarek F Maassarani, The Corporate Whistleblower's Survival Guide: A Handbook for Committing the Truth (San Francisco: Berret-Koehler Publishers, 2011) at 165; Janine Pascoe \& Michelle Welsh, "Whistleblowing, Ethics and Corporate Culture: Theory and Practice in Australia" (2011) 40 Comm L World Rev 144 at 144, 146; GC Rapp, "Four Signal Movements in Whistleblower Law: 1983-2013" (2013) 30 Hofstra Lab \& Empl LJ 389 at 389; Vivienne Brand, Sulette Lombard \& Jeff Fitzpatrick, "Bounty Hunters, Whistleblowers and a New Regulatory Paradigm" (2013) 41 Austral Bus L Rev 292 at 293; Olivia Dixon, "Honesty without Fear? Whistleblower Anti-Retaliation Protections in Corporate Codes of Conduct" (2016) 40 Melbourne UL Rev 168 at 169; Jim Mathiopoulos, Katrina Hogan \& Jean du Plessis, "Whistleblowing Reforms: A Critical Analysis of the Current Law and the New 'Bells and Whistles' Proposed" (2017) 35 Company and Securities Law Journal 261 at 262. 
within an organization. This makes it easier for corporate insiders with knowledge about wrongdoing to come forward and thus have a more positive impact on whistle-blowing behaviour, perhaps even more so than traditional regulatory measures. ${ }^{71}$ In turn, this could result in the increased exposure of delinquent conduct. As such, it is advantageous for the corporation itself to have well-developed systems of internal reporting, in that this serves to encourage insiders with information about wrongdoing to report internally first, rather than reporting to a regulator or the media, thus potentially preventing or limiting financial and reputational harm to the organization. ${ }^{72}$ In addition, the behaviour of directors and managers are likely to be influenced by an awareness of a greater likelihood of wrongdoing being disclosed by whistle-blowers, thus resulting in enhanced corporate accountability. ${ }^{73}$ It could further function as an important element in building a "corporate immune system," which, like a biological immune system, involves a corporation developing internal mechanisms to ward off threats. ${ }^{74}$

It could perhaps be argued that internal whistle-blowing frameworks may be superfluous where other "corporate governance tools" function well. Particularly relevant in this context is the notion of corporate gatekeepers - professionals such as auditors, credit-rating agencies, securities analysts, investment bankers, and lawyers - who play an important part in ensuring corporate accountability. ${ }^{75}$ At first glance, these "gatekeepers" could appear to be prime candidates to blow the whistle on corporate wrongdoing due to their access to inside information. They also appear to be "external" to the company in most cases and thus not exposed to whistle-blowing disincentives to the same extent as employee whistle-blowers, for example. In theory, one could argue that this fact, along with the reputational harm that could result from failure to disclose wrongdoing, would cause them to be more likely to blow the whistle on delinquent conduct. In addition, with a more direct line of access to the management of the corporation, these gatekeepers are usually not dependent on internal whistle-blowing systems in order to be able to disclose wrongdoing, thus offering a further justification that internal whistle-blowing systems are unnecessary.

However, it is important to note the risk of potential gatekeeper failure in particular instances, such as where there is a close relationship between the gatekeeper and management, leading to a "group-think" mentality ${ }^{76}$ and also where a gatekeeper depends on a major corporate client for most or all of his or her income. ${ }^{77}$ In cases such as these, "insider" whistle-blowers could play a very important role in providing

71 Harold Hassink, Meinderd de Vries \& Laury Bollen, “A Content Analysis of Whistleblowing Policies of Leading European Companies" (2007) 75 Journal of Business Ethics 25 at 26.

72 See e.g. Vivienne Brand \& Sulette Lombard, "Good Governance Practice in Relation to Corporate Whistleblowing" (2015) 67 Governance Directions 10 at 10.

73 As Justice Louis D Brandeis is famously to have said: "Sunlight is said to be the best of disinfectants; electric light the most efficient of policeman."

74 In relation to the development of a corporate immune system, see e.g. Omari Scott Simmons, "The Corporate Immune System: Governance from the Inside Out" (2013) U Ill L Rev 1131.

75 The concept of "corporate gatekeepers" is well known thanks to the work of commentators such as John Coffey. See e.g. John Coffey Jr, "Understanding Enron: 'It's about the Gatekeepers, Stupid"” (2001-2) 57 Business Lawyer 1403 [Coffey, "Understanding Enron"]; John Coffey Jr, Gatekeepers: the Professions and Corporate Governance (Oxford University Press, 2006) [Coffey, "Gatekeepers"].

76 KA Bamberger, "Regulation as Delegation: Private Firms, Decision Making, and Accountability in the Administrative State" (2006) 56 Duke LJ 377 at 432; see also S Mavrommati, "The Dynamics of Gatekeepers, Corporate Culture and Whistle Blowers" (2005) 1 Corporate Governance Law Review 385.

77 See Coffey, "Understanding Enron," supra note 75 at 1408-1416; Coffey, "Gatekeepers," supra note 75, ch 3, for a detailed discussion on reasons for gatekeeper failure. 
a more independent view. Even in circumstances where gatekeepers are functioning well, whistle-blowers could be valuable in providing relevant information to corporate gatekeepers, thus contributing to enhanced gatekeeping functionality. ${ }^{78}$ Well-developed internal reporting frameworks, therefore, could play an invaluable role not only in supporting gatekeeper activity but also in acting as a type of "safety net" in case of gatekeeper failure.

Thus, the advantages of well-developed internal systems to report wrongdoing seem obvious - not only from a regulatory perspective but also from the perspective of the corporation, which may benefit from insiders with knowledge about wrongdoing reporting internally first. In this way, there is an opportunity for the corporation to reduce the harm that could result from the wrongdoing and also an opportunity to potentially prevent reputational damage that could result from the information being made public in some way. As such, not surprisingly, many organizations appear to have voluntarily adopted some form of internal reporting mechanism. ${ }^{79}$

\section{The Regulation of Internal Whistle-blower Systems}

This raises the question of whether regulation should prescribe the development of internal reporting systems. Perhaps there is no need for regulation to ensure that corporations do develop internal whistleblowing systems and that corporations should be left to "self-regulate." One could argue that those corporations who choose not to develop such systems should be left to carry the "penalty" of, among other things, reputational harm where information about wrongdoing is disclosed externally due to a lack of internal reporting mechanisms. However, the flaw in this argument is that the "penalty" of not having such systems in place often falls not only on the corporation's management, which decided not to invest in internal whistle-blower reporting mechanisms, but also frequently on the shoulders of corporate stakeholders (such as shareholders and employees) and on the public generally if the fallout from the revelation of misconduct becomes widespread. In addition, some of the regulatory benefits of internal systems, such as alleviating the regulatory oversight burden and the positive impact on a corporate culture of transparency and accountability will be sacrificed if there is no internal reporting mechanism.

It is therefore submitted that the development of internal whistle-blowing systems should not be a purely voluntary measure but, rather, that some form of regulatory intervention is required. A well-framed regulatory message should motivate entities that have elected not to develop internal systems to adopt a system or to improve internal whistle-blowing systems that are not very sophisticated or effective. But the question remains, of course, as to how regulation should be framed so as to encourage the development of effective internal whistle-blowing systems in light of the clear benefits offered by such systems. In terms of whistle-blowing award programs administered by a regulator, there is also a second question namely, how such programs can enhance effective internal whistle-blowing systems and not undermine their development or operation.

As a result of the clear benefits of fostering internal whistle-blowing systems, a number of jurisdictions have adopted regulations to encourage corporate whistle-blowers to report misconduct internally. Often such regulations are intended to counteract the huge impediments that whistle-blowers typically face when

78 Sulette Lombard \& Vivienne Brand, "Whistleblowing and Corporate Governance: Regulating to Reap the Governance Benefits of 'Institutionalised' Whistleblowing" (2018) 36 Company and Securities Law Journal 29 at 33.

79 See Lombard \& Brand, supra note 78 at $42-45$ for information on the extent to which and how some Australian corporations adopted internal reporting systems. 
coming forward, ${ }^{80}$ and, as such, they are frequently focused on some form of whistle-blower protection from retaliation. ${ }^{81}$ Regulation can also be more prescriptive by requiring organizations to adopt internal whistle-blowing mechanisms, such as the requirements in $S O X$ referred to above that mandated that audit committees of public companies set up internal whistle-blowing procedures. More recently, the Financial Conduct Authority in the United Kingdom, after having rejected the idea of introducing a whistle-blower awards program, introduced a set of prescriptive rules for internal whistle-blowing systems. ${ }^{82}$

However, as demonstrated by the apparent failure of $S O X$ to encourage employees to blow the whistle in relation to the corporate failures exposed by events that contributed to the global financial crisis, perhaps direct regulation may not always be the most effective way to foster the effective design and implementation of internal whistle-blower mechanisms. In part, this may be because of the enormous variation in the complexity and structure of businesses within an economy. Accordingly, it may be the business itself, not the regulator, that is best placed to design an effective internal whistle-blower system. If that is in fact the case, direct regulation prescribing the design of the system may be ill-fitting, expensive to implement, and unreasonably burdensome, particularly if imposed on smaller businesses with limited resources. At worse, it may create a counter-productive "tick-the-box" mentality as to regulatory requirements and perhaps create an incentive to create a "Potemkin village" system to earn the business credit or a defence to liability if caught but which, in fact, is practically ineffective at encouraging and responding to reports of misconduct. ${ }^{83}$

However, absent direct regulation, the question remains as to how do regulators ensure that organizations adopt robust internal whistle-blower mechanisms? These questions may be better answered with reference to some theories of regulation that explore how to foster compliance and good governance practices without necessarily resorting to prescriptive rules.

\section{RESPONDING TO THE CHALLENGE OF DESIGNING EFFECTIVE INTERNAL WHISTLE-BLOWER FRAMEWORKS}

\section{A. New Governance, Smart Regulation, and Internal Compliance Mechanisms}

New governance has been described as a "moniker to refer to a new approach in legal scholarship that emphasizes not legal doctrine or formal jurisprudence, but rather how change actually happens within

80 Disincentives faced by whistle-blowers are well documented. See Frederick D Lipman, Whistleblowers: Incentives, Disincentives and Protection Strategies (Hoboken, NJ: John Wiley \& Sons, 2012).

81 See e.g. in the United States, see SOX, supra note 19 at para 806; in Canada, see Securities Act, RSO 1990, c S5, s 121.5; Commodity Futures Act, RSO c C20, s 54.1; in Australia, see Corporations Act 2001 (Cth), pt 9.4AAA, which is to be strengthened under reforms that are underway as set out in the Treasury Laws Amendment (Enhancing

Whistleblower Protections) Bill 2017.

82 These rules, adopted in October 2015, require that large firms must adopt internal whistle-blowing arrangements, appoint a senior manager as their "whistle-blowers" champion, inform employees about the Financial Conduct Authority's (FCA) whistle-blowing services, present a report on whistle-blowing to the board at least annually, incorporate text in settlement agreements explaining that workers have a legal right to "blow the whistle" and inform the FCA if it loses an employment tribunal action against a whistle-blower. See FCA, Press Release, "FCA Introduces New Rules on Whistleblowing" (6 October 2015), online: <https://www.fca.org.uk/news/press-releases/fca-introduces-new-ruleswhistleblowing $>$.

83 As to the challenges in regulators designing compliance systems, see generally Miller, supra note 66. 
complex real-life social systems." 84 It relies on industry knowledge and experience to allow the regulator to establish broad policy guidelines or principles and regulatory goals, but without the regulator prescribing those "principles" or how they should be achieved. ${ }^{85}$ New governance ideas challenge some of the concepts underpinning traditional, "command-and-control-type" regulation. ${ }^{86}$ It emphasizes

a public-private collaboration in designing own programs and structures; embraces a view of an external regulator as a "facilitator", rather than as a "centralised rule maker"; and promotes regulation strategies that are "decentralised", "bottom-up" or inside-out", with a concomitant preference for "incrementalism" and "flexible legal rules", rather than rules that are "rigid" and "prescriptive" ... [thus allowing] entities that are regulated to be involved in the setting of appropriate standards. ${ }^{87}$

A regulatory approach based on new governance ideals would therefore be "principles-based (as opposed to providing a set of prescriptive rules), outcome-driven and relying on interaction and co-operation between the regulator and entities being regulated." 88

Christie Ford notes that there is a critical nexus between a principles-based, new governance-style approach and "policies, processes, and systems that firms themselves must have in place to prevent and detect internal wrongdoing and violations of law." 89 Therefore, the essential nature of well-developed internal whistle-blowing systems in the context of new governance-type regulation seems clear. However, while new governance emphasizes a principles-based approach, Ford also notes that within this credible enforcement is a necessary component of principles-based and outcome-oriented regulation (meaning both compliance oversight and prosecution, where needed) since such new governance theory is to be distinguished from industry self-regulation and also from so-called "soft law" options. In fact, meaningful and effective enforcement capacity is a precondition to new governance regulation. ${ }^{90}$

The extent of external enforcement that is required in the new governance context could potentially be assessed through the lens of the well-known "responsive regulation" theory. Responsive regulation has at its core the idea that regulators should be "responsive to the conduct of those they seek to regulate in deciding whether a more or less interventionist response is needed" and should consider "how effectively citizens or corporations are regulating themselves before deciding whether to escalate intervention." 91 The

84 Christie Ford, "New Governance, Compliance, and Principles-Based Securities Regulation” (2008) 45:1 Am Bus LJ 1 at 27.

85 Ibid.

86 Edward L Rubin, "The Regulatizing Process and the Boundaries of New Public Governance” (2010) Wis L Rev 353 at 356, with reference to Norbert Elias, The Civilizing Process: The History of Manners and State Formation and Civilization, translated by Edmund Jephcott (Oxford: Blackwell 1994). It was originally published in German as two volumes in 1939: Norbert Elias, The History of Manners (Basel: Haus zum Falker, 1939); Norbert Elias, State Formation and Civilization (Basel: Haus zum Falker, 1939).

87 Lombard \& Brand, supra note 78 at 36, with reference to Simmons; Jason M Solomon "New Governance, Preemptive Self-Regulation, and the Blurring of Boundaries in Regulatory Theory and Practice" (2010)

Wis L Rev 591.

88 Lombard \& Brand, supra note 78 at 36.

89 Ford, supra note 84 at 28.

$90 \quad$ Ibid at 32.

91 John Braithwaite, Restorative Justice and Responsive Regulation (New York: Oxford University Press, 2002 ) at 29. 
operation of responsive regulation is typically illustrated through John Braithwaite's well-known regulatory enforcement pyramid presented in Figure $1 .{ }^{92}$

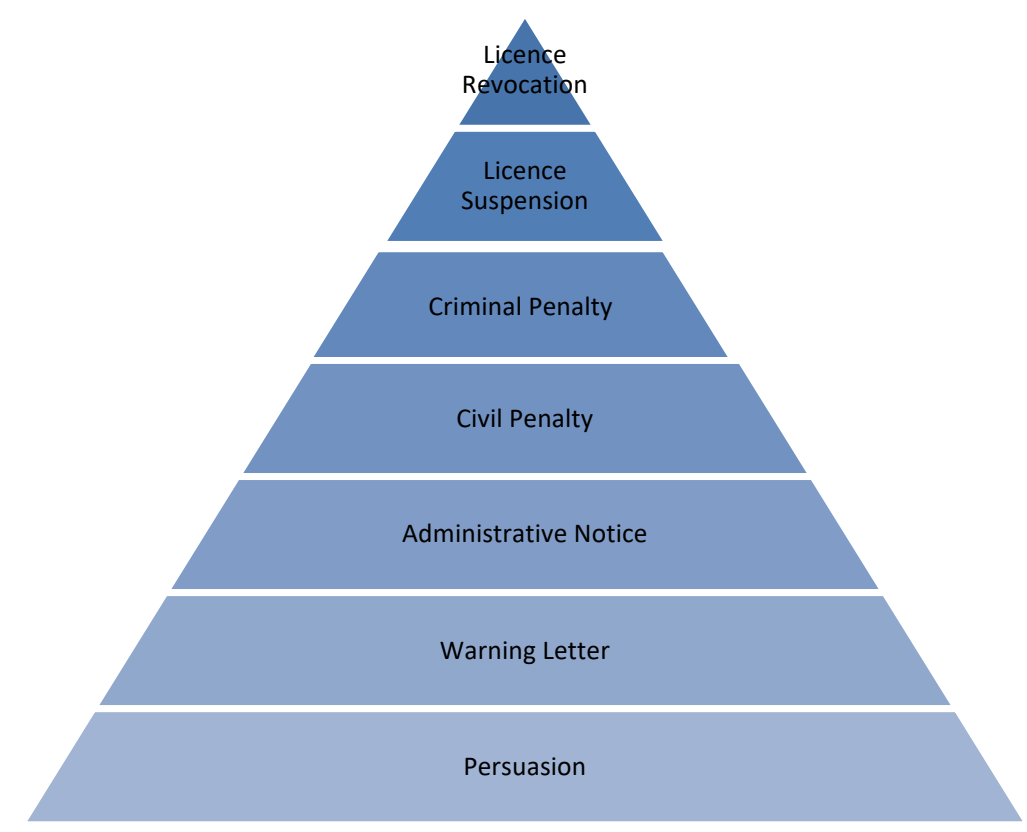

Figure 1: Regulatory Pyramid, Oxford University Press

The regulatory pyramid is based on the principle that, in order to achieve a desired regulatory outcome, the "sanction" for non-compliance with regulations should be as unintrusive as possible to start with but that it should become increasingly severe higher up the pyramid..$^{93}$ It is also suggested that increasing intrusiveness is matched by decreasing frequency of use. ${ }^{94}$

If it is accepted that the desired regulatory outcome is corporations developing effective internal whistle-blowing frameworks, how do these core principles of responsive regulation guide the framing of the relevant regulation, particularly with reference to the "sanction" or the consequences where corporations do not demonstrate the desired regulatory outcome? One would argue that corporations that are "effectively regulating themselves" to the extent that they have effective and sophisticated internal whistle-blowing systems should not be subject to "regulatory sanctions." In principle, this approach seems sound, and it seems sensible that companies that pay careful attention to the design and implementation of effective systems of internal reporting should be subject to the least amount of regulatory intervention, as they are demonstrating the achievement of the desired regulatory outcome. This conclusion would also appear to be supported by the approach illustrated in the responsive regulation pyramid.

92 First put forward in John Braithwaite, To Punish or Persuade: Enforcement of Coal Mine Safety (Albany, NY: State University of New York Press, 1985).

93 Ian Ayres \& John Braithwaite, Responsive Regulation: Transcending the Deregulation Debate (Oxford University Press, New York, 1992) at 35-36.

94 Ibid. 
However, as the pyramid illustrates, the effective operation of this approach relies on some form of "rule" that can ultimately be enforced where the "softer" layers of regulation at the bottom parts of the pyramid fail to achieve the desired outcome. Following this application to its logical conclusion, one would argue that, in terms of external regulations, it assumes a "duty" on corporations to develop effective internal whistle-blowing frameworks, non-compliance with which could ultimately be punished by means of penalties or suspensions. This approach seems to be less closely aligned with principles of new governance that rely on collaboration rather than on the "top-down" enforcement approach, which would seem to be suggested by the regulatory pyramid and appears to be more aligned with a "rules-based" approach rather than a "principles-based" approach in some ways.

A rules-based, top-down approach is open to criticism for a number of reasons. First, it would ultimately lead to an increased regulatory burden because of the inherent requirement that it has to be "policed" and sanctioned in cases of non-compliance. ${ }^{95}$ Second, the top-down approach is unlikely to achieve the same amount of success in "internalizing" norms such as disclosure, transparency, and accountability - ultimately, improving corporate culture - as would be the case with an "inside-out" approach that aligns with new governance notions. ${ }^{96}$ Third, it carries the risk of corporations adopting a "box-ticking" approach aimed purely at complying with external regulation rather than at giving careful thought to the design and implementation of bespoke internal whistle-blowing frameworks that would operate effectively in that particular organization to encourage insiders with knowledge about wrongdoing to report. Fourth, regulation in this sphere could potentially opt for a "one-size-fits-all" approach in relation to the elements that should constitute an internal whistle-blowing framework; this might either be based on the lowest common denominator level of internal reporting or not provide sufficient flexibility to recognize different contexts of organizations.

It would therefore appear as if the exclusive application of the responsive regulation-type model, as illustrated in terms of the regulatory pyramid, may be contrary to regulatory approaches framed in accordance with principles of new governance, which advocate against a "top-down, rules-based" type of approach. Instead, it is submitted that a "smart regulation" approach might be more useful in the context of the design of internal whistle-blowing systems. Smart regulation refers to "a form of regulatory pluralism that embraces flexible, imaginative and innovative forms of ... control," harnesses enforcementtype activities of "governments as well as business and third parties," "97 and "highlights the importance of utilising combinations of instruments and parties to compensate for weakness of standalone ... policies." 98 It builds on the concept of the regulatory pyramid above and adds two more faces: a second face of "selfregulation" and a third face recognizing activities by commercial and/or non-commercial third parties, thus resulting in a three-sided enforcement pyramid. ${ }^{99}$ Smart regulation allows for "the possibility of regulation using a number of different instruments implemented by [a] range of parties ... with escalation to higher levels of coerciveness not only within a single instrument category, but also across several

\footnotetext{
95 Lombard \& Brand, supra note 78 at 38.

96 Ibid.

97 Neil Gunningham \& Darren Sinclair, "Smart Regulation” in Peter Drahos, ed, Regulatory Theory: Foundations and Applications (Australia: Australian National University Press, 2011) 133 at 133.

$98 \quad$ Ibid at 139.

99 Ibid at 135.
} 
different instruments and across different faces of the pyramid."100 Neil Gunningham and Darren Sinclair list a number of policy instrument categories - namely, command-and-control regulation, economic instruments, self-regulation, voluntarism, and information strategies and illustrate how particular combinations of these can achieve effective and efficient regulatory outcomes and warn against adopting non-complementary combinations. ${ }^{101}$ This approach has been adopted in jurisdictions across the globe, ${ }^{102}$ including Canada. ${ }^{103}$

The concept of pluralism underpinning smart regulation appears attractive in the context of regulation to encourage the development of internal whistle-blowing frameworks and seems to fit well with notions of new governance. However, taking heed of the warning issued by Gunningham and Sinclair, it is important that any regulation based on this approach carefully considers the complementarity of instrument combinations and, in line with Ford's concerns, contain a "credible enforcement" element. ${ }^{104}$ It is suggested that a combination of voluntarism (being based on "individual firms undertaking to do the right thing unilaterally"105) and command-and-control-type regulation in relation to disclosure could be useful for achieving desired regulatory outcomes with respect to the development of internal whistleblowing frameworks.

\section{B. Nudge Theory}

"Nudge" theory is also valuable in this context to describe how regulation could be designed to achieve the desired regulatory outcome, with the least intrusive measures possible. "A nudge" is defined as

any aspect of the choice architecture that alters people's behaviour in a predictable way without forbidding any options or significantly changing their economic incentives. To count as a mere nudge, the intervention must be cheap and easy to avoid. Nudges are not mandates. Putting fruit at eye level [hoping that people then choose fruit over unhealthy alternatives] counts as a nudge. Banning junk food does not. ${ }^{106}$

David Halpern describes it as "a means of encouraging or guiding behavior but without mandating or instructing, and ideally, without the need for heavy financial incentives or sanctions."107

100 Ibid at 137 (Emphasis in original).

101 Ibid at 141.

102 Ibid at 143-144 provide examples of regulation in Canada and the European Union that went under this banner, mentioning, in particular, the Canadian government's regulatory reform program under this banner in the mid-2000s.

103 E.g., in January 2005, Environment Canada launched the Smart Regulation Project. Environment Canada, Improving the Effectiveness and Efficiency of Pulp and Paper Environmental Effects Monitoring (December 2005), online: $<$ http://ec.gc.ca/esee-eem/default.asp?lang=En\&n=96B3035D-1>.

104 Ford, supra note 84 at 28.

105 Gunningham \& Sinclair, supra note 97 at 140.

106 Richard H Thaler \& Cass R Sunstein, Nudge: Improving Decisions about Health, Wealth and Happiness (London: Penguin Books, 2008) at 6, as referred to by Joroen van der Heijden \& Mark Kosters, "From Mechanism to Virtue: Evaluating Nudge Theory" (2015) 21:3 Evaluation 276 at 278-279.

107 David Halpern, Inside the Nudge Unit: How Small Changes Can Make a Big Difference (London: WH Allen, 2015) at 22, as referred to by Carolyn Pedwell, "Habit and the Politics of Social Change: A Comparison of Nudge Theory and Pragmatist Philosophy" (2017) 23:4 Body \& Society 59 at 67. 
Nudge theory suggests that corporations, for example, could be influenced to adopt internal whistleblowing frameworks by a requirement to report on the existence/operation of such frameworks, signalling the importance of having such systems in place without imposing a "rule" that all corporations should have particular frameworks in place. ${ }^{108}$ This reporting could be done as part of regular reporting obligations, thus avoiding imposing an additional burden on corporations, or on the regulator, to ensure that the reporting obligation is complied with. In this way, the much-need "enforcement" element is present, albeit not in relation to a rule prescribing the development of internal whistle-blowing frameworks but, instead, in relation to an existing, but augmented, reporting obligation.

In addition, another regulatory obligation - one that serves to protect whistle-blowers; non-compliance with which would lead to liability - could be linked to internal whistle-blowing frameworks. For example, the availability of well-developed, transparent, and accessible internal systems could be a factor meriting consideration in assessing whether a corporation complied with this obligation and should be accorded leniency in terms of enforcement action and penalties. Once again, internal systems as such are not being mandated, but through the adoption of a particular regulatory approach, corporations are "nudged" towards adopting such systems. In line with the principles of new governance, ${ }^{109}$ it is a principle-based, collaborative approach. However, it is also an approach that links to "responsive" enforcement by way of ultimate liability where it is found that the obligation to protect whistle-blowers has not been complied with.

Compared to direct "rules-based" regulation mandating the adoption of internal frameworks, the approaches above seem to carry a number of benefits. These include the benefits of flexibility to allow corporations to develop internal whistle-blowing frameworks suitable to their circumstance. They also require less regulatory oversight and could potentially lead to the development of more sophisticated and effective systems than would be the case if a "lowest common denominator, check-box type of approach was developed on the basis of rule-based regulation. Furthermore, they should ultimately create an environment where the norms underpinning the reporting of wrongdoing would be internalized and contribute to improved corporate culture.

\section{Whistle-blower Award Programs and Internal Whistle-blowing Systems}

How then do whistle-blower award programs fit within this framework? This is a particularly pertinent question in light of concerns that have been raised about the potential detrimental impact of whistleblowing bounties on the use and relevance of internal reporting systems. Specifically, the concern is that the existence of a whistle-blower awards program could affect whistle-blower behaviour, in that whistleblowers may elect to directly report externally to increase the chances of obtaining the whistle-blowing

108 Richard Moberly, "Sarbanes-Oxley's Structural Model to Encourage Corporate Whistleblowers" (2006) 5 BYUL Rev 1107 at 1169-1170, notes the value of mandatory disclosure in relation to internal corporate whistle-blower systems.

109 However, note the criticism of Miriam H Baer, "Governing Corporate Compliance" (2009) 50 Boston College L Rev 949, at 1009-1015, who notes that [m]andatory reporting requirements are not the equivalent of New Governance" (at 1013) and who warns against the risk of inappropriately labelling of regulatory approaches as "new governance." 
reward. ${ }^{110}$ This could subvert the relevance of internal whistle-blowing systems that would in turn affect the preparedness of corporations to develop effective and sophisticated internal reporting mechanisms.

One "solution" could be to compel whistle-blowers to use internal systems, provided that these exist, before they can report externally. The increased likelihood of whistle-blowers reporting externally due to the availability of a financial reward, could therefore serve as a "nudge" to prod corporations to develop internal systems, seeing that this could prevent whistle-blowers reporting directly to an external body. However, there is an inherent risk to a mandatory "internal first" approach in that it leaves corporations free to develop substandard internal reporting frameworks, while preventing the whistle-blower from reporting externally and also does not provide an incentive to respond to the disclosure by the whistleblower. ${ }^{111}$ Any regulatory "nudge" offered by the availability of whistle-blowing awards will therefore only be really effective if it also contains elements aimed at the quality of the internal framework as well as the responsiveness to disclosures.

Both the SEC and the OSC's whistle-blowing award policies demonstrate how regulation can be framed to address these concerns. ${ }^{12}$ Both attempt to achieve desired regulatory objectives by "incentivizing" whistle-blowers to report internally first, without mandating them to do so, through linking the amount of the reward to the efforts of the whistle-blower to use internal reporting channels. ${ }^{113}$ Both also allow whistle-blowers to access a reward even if they report internally first, provided that their employer reports to the regulator and provided that the whistle-blower also informs the regulator within 120 days of making the internal report. ${ }^{114}$ Baer notes that "[o]ne advantage of whistleblowing award programs is that it 'induces a quasi-competition for information,' forcing the corporations compliance department to take the employee's claim more seriously knowing that the employee can easily (and perhaps more profitably) report the information to the SEC." 115 As such, whistle-blowing award programs can therefore serve to "nudge" corporation behaviour in regard to responding to disclosures by whistleblowers.

In relation to the SEC's whistle-blower awards program at least, these measures are apparently proving to be successful, and this evidence indicates that most whistle-blowers first report internally. ${ }^{116}$ This suggests that whistle-blowers are willing to report internally first and only go outside of the organization if their concerns are not appropriately addressed. As such, a truly effective internal compliance program, which employees can use without any fear of retaliation and which resolves the employees concerns, can compete effectively with external whistle-blower award programs. As such, whistle-blower award

110 SEC Implementation of Section $21 F$, supra note 2 at 5 , indicates that "[a] significant issue discussed in the Proposing Release was the impact of the whistleblower program on companies' internal compliance processes." Commentators voiced similar concerns. See e.g. Dave Ebersole, "Blowing the Whistle on the Dodd-Frank Whistleblower Provisions" (2011) 6 Ohio State Entrepreneurial Business Law Journal 123 at 138-139; see also Justin Blount \& Spencer Markel, "The End of the Internal Compliance World as We Know It, or an Enhancement of the Effectiveness of Securities Law Enforcement? Bounty Hunting under the Dodd-Frank Act's Whistleblower Provisions" (2012) 17 Fordham J Corp \& Fin L 1023, for an overview of concerns and responses to concerns in this regard.

111 Blount \& Markel, supra note 110 at 1055.

112 See SEC Implementation of Section $21 F$, supra note 2, rules 21F-4(b)(7), 21F-4c.

113 See e.g. Blount \& Markel, supra note 110 at 1055, with reference to 17 CFR $\S \S 240.21 \mathrm{~F}-6$ (2011).

114 Blount \& Markel, supra note 110 at 1055, with reference to 17 CFR $§ 240.21 \mathrm{~F}-4$ (c)(3) (2011).

115 Baer, supra note 18 at 2240.

116 SEC 2017 Annual Report, supra note 4. 
programs can be seen as complementing, rather than undermining, internal compliance and, when framed properly, could "nudge" corporate behaviour in a particular way. ${ }^{117}$

It seems then that the SEC's and OSC's whistle-blower award programs perhaps do strike an appropriate balance between internal and external reporting. Both incentivize internal reporting but do not make it mandatory. Both allow a window of opportunity to self-report and offer leniency to companies who do self-report. These are all good examples of a regulatory "nudge" to ensure that corporations have effective, well-publicized internal systems in place without the need for prescriptive regulation. On the other hand, there is also a regulatory "nudge" to encourage whistle-blowers to use internal systems by linking their efforts in this regard to the amount of the reward.

\section{CONCLUSION}

The corporate governance benefits offered by internal whistle-blowing mechanisms, valuable as they are, are not sufficient to obviate the need for regulatory oversight. The need to foster effective internal whistle-blowing mechanisms extends beyond the need to ensure the good governance of the corporation. Effective internal whistle-blowing mechanism systems are necessary to reduce the harm associated with corporate fraud and misconduct not only to the corporation itself but also to the economy generally. As such, effective regulatory measures to ensure such mechanisms are in place are critical to avoid the pitfalls or "dark side" of relying exclusively on notions of governance that have been noted by many commentators, ${ }^{118}$ particularly around the potential lack of accountability. ${ }^{119}$

Regulatory theory - particularly, around concepts inherent to new governance - could offer useful strategies as to how to achieve these desired regulatory outcomes and seem particularly appropriate for the design of policies and systems that firms themselves must have in place to detect and respond to wrongdoing and misconduct, such as internal whistle-blowing mechanisms. The SEC's and OSC's whistle-blower award programs seem to fit within this new governance approach. Such award systems can operate so that the ultimate regulation - in this case, the development of robust and effective internal compliance systems - results from "negotiation" and "nudges" between the regulator and stakeholders and not from prescriptive rules. Accordingly, other jurisdictions that may be considering how to encourage best practices in relation to internal compliance systems may want to consider the impact of whistleblower awards systems. It may be that such award systems can form an important element of a regulatory framework, provided, of course, that the award system is carefully constructed so that it works with, and not against, the design and implementation of robust internal whistle-blowing systems.

117 See generally Clair Sylvia \& Emily Stabile, "Rethinking Compliance: The Role of Whistleblowers" (2016) 84 U Cin L Rev 451.

118 See e.g. Jorg Raab \& H Brinton Milward, "Dark Networks as Problems" (2003) 13:4 Journal of Public Administration Resolution Theory 413.

119 Lombard \& Brand, supra note 78 at 30. 